\title{
Effects of subcutaneous glucagon-like peptide 1 (GLP-1 [7-36 amide]) in patients with NIDDM
}

\author{
M .A . N auck ${ }^{1}$, D. Wollschläger ${ }^{2}$, J. Werner ${ }^{2}$, J J . H olst ${ }^{3}$, C . Ø rskov ${ }^{3}$, W. C reutzfeldt ${ }^{4}$, B. Willms ${ }^{2}$ \\ ${ }^{1}$ D epartment of M edicine, R uhr-U niversity B ochum, K nappschafts-K rankenhaus, B ochum, G ermany \\ ${ }^{2}$ Fachklinik für D iabetes und Stoffwechselkrankheiten, B ad L auterberg, G ermany \\ ${ }^{3}$ D epartments of $A$ natomy and Physiology, Panum Institute, $U$ niversity of Copenhagen, D enmark \\ ${ }^{4}$ D ivision of $\mathrm{G}$ astroenterology and $\mathrm{E}$ ndocrinology, D epartment of M edicine, G eorg-A ugust-U niversity, G öttingen, G ermany
}

Summary Intravenous glucagon-like peptide (GLP)1 [7-36 amide] can normalize plasma glucose in noninsulin-dependent diabetic (NID D M) patients. Since this is no form for routine therapeutic administration, effects of subcutaneous GLP-1 at a high dose (1.5 $\mathrm{nmol} / \mathrm{kg}$ body weight) were examined. Three groups of 8,9 and 7 patients $(61 \pm 7,61 \pm 9,50 \pm 11$ years; BMI $29.5 \pm 2.5,26.1 \pm 2.3,28.0 \pm 4.2 \mathrm{~kg} / \mathrm{m}^{2} ; \mathrm{HbA}_{1 \mathrm{c}}$ $11.3 \pm 1.5,9.9 \pm 1.0,10.6 \pm 0.7 \%$ ) were examined: after a single subcutaneous injection of $1.5 \mathrm{nmol} / \mathrm{kg}$ G LP [7-36 amide]; after repeated subcutaneous injections ( 0 and $120 \mathrm{~min}$ ) in fasting patients; after a single, subcutaneous injection 30 min before a liquid test meal (amino acids $8 \%$, and sucrose $50 \mathrm{~g}$ in $400 \mathrm{ml}$ ), all compared with a placebo. Glucose ( $\mathrm{glu}$ cose oxidase), insulin, C-peptide, GLP-1 and glucagon (specific immunoassays) were measured. $G$ astric emptying was assessed with the indicator-dilution method and phenol red. R epeated measures A N O VA was used for statistical analysis. G LP-1 injection led to a short-lived increment in G LP-1 concentrations (peak at 30-60 min, then return to basal levels after 90-120 min). E ach G LP-1 injection stimulated insulin (insulin, $\mathrm{C}$-peptide, $\mathrm{p}<0.0001$, respectively) and inhibited glucagon secretion $(p<0.0001)$. In fasting patients the repeated administration of GLP-1 normalized plasma glucose $(5.8 \pm 0.4 \mathrm{mmol} / \mathrm{l}$ after $240 \mathrm{~min}$ vs $8.2 \pm 0.7 \mathrm{mmol} / \mathrm{l}$ after a single dose, $p=0.0065$ ). With the meal, subcutaneous G L P-1 led to a complete cessation of gastric emptying for 30 $45 \mathrm{~min}$ ( $p<0.0001$ statistically different from placebo) followed by emptying at a normal rate. A s a consequence, integrated incremental glucose responses were reduced by $40 \%(p=0.051)$. I n conclusion, subcutaneous G LP-1 [7-36 amide] has similar effects in NIDDM patients as an intravenous infusion. Preparations with retarded release of GLP-1 would appear more suitable for therapeutic purposes because elevation of GLP-1 concentrations for 4 rather than $2 \mathrm{~h}$ (repeated doses) normalized fasting plasma glucose better. In the short term, there appears to be no tachyphylaxis, since insul in stimulation and glucagon suppression were similar upon repeated administrations of GLP-1 [7-36 amide]. It may be easier to influence fasting hyperglycaemia by G LP-1 than to reduce meal-related increments in glycaemia. [D iabetologia (1996) 39: 1546-1553]

Keywords G L P-1 [7-36 amide], incretin, insulin, glucagon, pharmacokinetics.
Corresponding author: Priv.-D oz. D r. med. M . Nauck, D epartment of Medicine, R uhr-U niversity Bochum, K nappschaftsK rankenhaus, In der Schornau 23-25, D -44892 B ochum, G ermany

A bbreviations: BMI, Body mass index; EDTA, ethylene diamine tetra-acetic acid; GIP, gastric inhibitory polypeptide; G L P-1, glucagon-like peptide-1; R M -A NOVA, repeated measures analysis of variance; NIDD M , non-insulin-dependent diabetes mellitus; IR, immunoreactive.
G lucagon-like peptide 1 (G L P-1) [7-36 amide] is an insulinotropic hormone secreted from enteroglucagon-producing $L$ cells in the lower gut, i. e. the ileum and colon/rectum [1, 2]. GLP-1 [7-36 amide], together with gastric inhibitory polypeptide (GIP) from the upper gut, acts as a physiological incretin hormone $[3,4]$. In pharmacological concentrations, exogenous G LP-1 [7-36 amide or 7-37] also raised insulin and lowered glucagon concentrations in 
Table 1. Characteristics of NIDDM patients studied

\begin{tabular}{|c|c|c|c|c|}
\hline G LP-1 [7-36 amide] s. C.: & $\begin{array}{l}\text { Study A } \\
\text { Fasting patients } \\
\text { Single dose }\end{array}$ & $\begin{array}{l}\text { Study B } \\
\text { Fasting patients } \\
\text { R epeated dose }\end{array}$ & $\begin{array}{l}\text { Study C } \\
\text { Liquid meal } \\
\text { Single dose }\end{array}$ & $\begin{array}{l}\text { Significance } \\
\text { A NOVA } \\
\text { ( } p \text {-value) }\end{array}$ \\
\hline 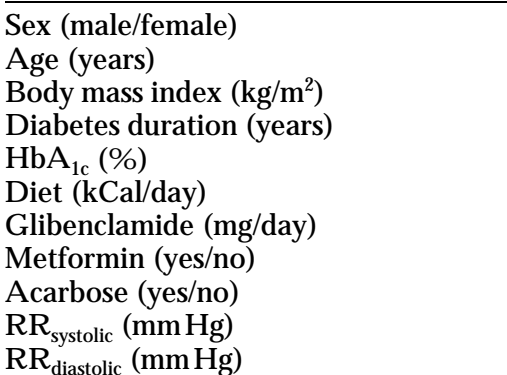 & $\begin{array}{l}5 / 3 \\
61 \pm 7 \\
29.5 \pm 2.5 \\
9 \pm 3 \\
11.3 \pm 1.5 \\
1429 \pm 262 \\
9.6 \pm 2.5 \\
1 / 7 \\
1 / 7 \\
162 \pm 28 \\
94 \pm 16\end{array}$ & $\begin{array}{l}4 / 5 \\
61 \pm 9 \\
26.1 \pm 2.3 \\
11 \pm 7 \\
9.9 \pm 1.0 \\
1538 \pm 348 \\
10.5 \pm 0 \\
2 / 7 \\
0 / 9 \\
138 \pm 19 \\
72 \pm 13\end{array}$ & $\begin{array}{l}3 / 4 \\
50 \pm 11 \\
28.0 \pm 4.2 \\
10 \pm 4 \\
10.6 \pm 0.7 \\
1416 \pm 253 \\
10.5 \pm 0 \\
6 / 1 \\
0 / 7 \\
136 \pm 12 \\
82 \pm 11\end{array}$ & $\begin{array}{l}0.69 \\
0.03 \\
0.096 \\
0.59 \\
0.054 \\
0.66 \\
0.39 \\
0.007 \\
0.35 \\
0.043 \\
0.012\end{array}$ \\
\hline
\end{tabular}

$\mathrm{D}$ ata are mean $\pm \mathrm{SD}$

non-insulin-dependent diabetic (NIDDM) patients $[5,6]$. B y these mechanisms, plasma glucose was normalized within 3-4 $\mathrm{h}$ by i.v. G LP-1 [7-36 amide] in NIDDM patients with secondary failure of sulphonylurea treatment [7]. Therefore, GLP-1 [7-36 amide] or G LP-1 [7-37] (which has an identical action profile in rats [8], normal humans [9] and NIDDM patients [10]) has been suggested for use in the therapy of NIDDM patients [5-7, 10, 11]. However, a mode of administration has to be sought that both makes use of the potential to normalize glycaemia in NIDDM patients $[7,10]$ and that will be acceptable when compared with other current therapy. O ne obvious way is the S.c. administration of this peptide hormone. Limited experience using small doses of GLP-1 [7-36 amide] have been reported by G utniak et al. [12]. H owever, they only used it to reduce postprandial glycaemic excursions. G LP-1 [736 amide] was injected shortly before the ingestion of a meal, and the effects noted were smaller in comparison to the normalization of fasting hyperglycaemia that can be achieved by i.v. G L P-1 [7-36 amide] in NIDDM patients $[6,10]$. Since i.v. GLP-1 [7-36 amide] profoundly influences fasting hyperglycaemia in NIDDM patients $[7,10]$, it was the aim to also examine the effect of S.C. GLP-1 in fasting patients, and to compare it to a preprandial administration. The amount administered in the present study was the maximum dose that was free of severe side-effects in young, healthy volunteers [13]. Preliminary results have been communicated in abstract form [14].

\section{Subjects, materials and methods}

Study protocol. The study protocols were approved by the ethics committee of the medical faculty of the G eorg-A ugust $U$ niversity, Göttingen, prior to the study. Written, informed consent was obtained from all participants.

Subjects. Three groups of NID D M patients were studied, having been admitted to a specialized diabetes clinic because of unsatisfactory metabolic control. Their characteristics are shown in Table 1. A II were treated with diet and oral agents (sulphonylurea in all, plus acarbose or metformin in some). Diabetes, on average, had been diagnosed approximately 10 years earlier. $M$ etabolic control at the time of the study, as indicated by $\mathrm{HbA}_{1 \mathrm{c}}$ values of $10-11 \%$ (normal: 4.3-6.1\%), was unsatisfactory. M ost patients were slightly obese.

A II patients were studied on two occasions; in randomized order, in a single-blind fashion, placebo $(0.9 \% \mathrm{NaCl}$ with $1 \%$ human serum albumin) or GLP-1 [7-36 amide] in a dose of $1.5 \mathrm{nmol} / \mathrm{kg}$ body weight was administered in the morning after an overnight fast as a single or repeated dose. A nti-diabetic medication (Table 1 ) was given until the night before the first experiment. Between the experiments, 1 day with a regular eating and treatment schedule (including all drugs) was allowed.

Three protocols were compared: Study A examined the effect of a single s.c. injection of G L P-1 [7-36 amide] (administered at time $0 \mathrm{~min}$ ) in fasting NIDDM patients followed for 240 min. Study B examined the effect of a repeated s. c. injection of GLP-1 [7-36 amide] (administered at time 0 and $120 \mathrm{~min}$ ) in fasting NIDDM patients followed for $240 \mathrm{~min}$. Study $C$ examined effects of a preprandial single s. c. injection of GLP-1 [7-36 amide] (administered at time $-30 \mathrm{~min}$ ) in NIDDM patients. A t time 0 min, a liquid mixed meal made up of a commercially available amino acid solution (A minosteril N-H epa $8 \%$; Fresenius A G, Bad H omburg, G ermany) and sucrose ( $50 \mathrm{~g}$ per $400 \mathrm{ml}$ ) was administered via a nasogastric tube. R esults were observed over $240 \mathrm{~min}$.

Peptides. Synthetic GL P-1 [7-36 amide] was purchased from Saxon Biochemicals $\mathrm{GmbH}$, Hannover, G ermany (PGAS 242). The peptide was dissolved in $0.9 \% \mathrm{NaCl}$ containing $1 \%$ human serum albumin (M erieux, Norderstedt, G ermany), filtered through $0.2 \mu \mathrm{m}$ nitrocellulose filters (M illipore, Bedford, M ass., USA) and stored frozen at $-30^{\circ} \mathrm{C}$ as previously described $[4,5,7]$. Net peptide content rather than gross weight was used for dose calculations. $\mathrm{H}$ igh performance liquid chromatography profiles (provided by the manufacturer) showed that the preparation was more than $99 \%$ pure (single peak coeluting with appropriate standards). Samples were analysed for bacterial growth (standard culture techniques) and for pyrogens (Limulus amebocyte lysate endo-LAL, Chromogenix A B, M ölndal, Sweden). No bacterial contamination was detected. Endotoxin concentrations in the G LP-1 [7-36 amide] stem solutions were always less than 0.03 endotoxin units (EU)/ml. 
Experimental procedures. O ne forearm vein was punctured with a teflon cannula (M oskito 123, 18 gauge; $V$ ygon, A achen, Germany), and kept patent using $0.9 \% \mathrm{NaCl}$.

In experiments with fasting NID D M patients, after drawing basal blood specimens, at 0 min, G L P-1 [7-36 amide] was administered S. C. into the periumbilical region. The injected volume was $1 \mathrm{ml}$ per $85 \mathrm{~kg}$ body weight. In study B, at $120 \mathrm{~min}$ the subcutaneous injection of GLP-1 [7-36 amide] was repeated.

Blood specimens. B lood was drawn into heparinized tubes (immunoreactive [IR] insulin and C-peptide measurements). A sample was stored in N aF ( $\mathrm{M}$ icrovette CB 300; Sarstedt, N ümbrecht, Germany) for the measurement of glucose. For glucagon and G L P-1 [7-36 amide] measurements, blood was drawn into tubes containing ethylene diamine tetra-acetic acid (EDTA) and aprotinin (Trasylol; 20000 kallikrein inhibitor units/ml, $200 \mu$ l per $10 \mathrm{ml}$ blood; B ayer A G, L everkusen, G ermany). A fter centrifugation, plasma for hormone analyses was kept frozen at $-30^{\circ} \mathrm{C}$.

G astric emptying. In study $C$, before the start of the experiments, a nasogastric tube (Freka-E rnährungssonde, $120 \mathrm{~cm}$, $\mathrm{CH} \mathrm{12,} \mathrm{Fresenius} \mathrm{A} \mathrm{G} \mathrm{)} \mathrm{was} \mathrm{placed} \mathrm{and} \mathrm{tape-fixed} \mathrm{with} \mathrm{the} \mathrm{tip}$ approximately $55 \mathrm{~cm}$ from the nostrils. $\mathrm{G}$ astric juice was aspirated and an acid $\mathrm{pH}$ was ascertained using $\mathrm{pH}$-sensitive lackmus paper. The gastric lumen was washed with $100 \mathrm{ml}$ tap water warmed to $37^{\circ} \mathrm{C}$. If instilled water could not be completely aspirated, the position of the tube was adjusted to allow a near-complete aspiration of instilled fluid. The patients were in a semi-recumbent position, with the upper body $45^{\circ}$ upright. A t - 30 min, G L P-1 [7-36 amide] was administered s. C., and at $0 \mathrm{~min}$, the liquid meal (warmed to $37^{\circ} \mathrm{C}$ ) was instilled into the stomach. Previous studies had indicated peak plasma concentrations around $30 \mathrm{~min}$ after S.c. injection of GLP-1 [7-36 amide] [13]. The meal consisted of $32 \mathrm{~g}$ mixed amino acids ( $131 \mathrm{kCal}=40 \%$ of total caloric content) and $50 \mathrm{~g}$ sucrose ( $196 \mathrm{kCal}=60 \%$ ). Total energy content was $327 \mathrm{kCal}$ (energy density $0.82 \mathrm{kCal} / \mathrm{ml}$ ) $[15,16]$.

G astric emptying was determined exactly as in a previous study testing intravenously infused GLP-1 [7-36 amide] in a similar group of NIDDM patients [15], by a double-sampling dye dilution technique using phenol red (M erck A G, D armstadt, Germany), according to $G$ eorge [17], with modifications introduced to reduce the measurement error by $\mathrm{H}$ urwitz et al. [18]. In principle, at all time-points chosen to measure gastric volume, a known amount of the non-absorbable phenol red dye was added to the translucent test meal in a volume of 5 to $15 \mathrm{ml}$. A fter thorough mixing with gastric contents for approximately 2 min, a gastric sample was drawn, and the resulting step-up in phenol red concentrations was determined photometrically. Increasing amounts of phenol red were used as the experiments proceeded to obtain clearly measurable increments in optical density also in the presence of previously instilled phenol red [18]. In vitro, this method measured gastric volume with an accuracy of less than $6 \%$ (coefficient of variation).

$\mathrm{L}$ aboratory determinations. G lucose was measured using a glucose oxidase method with a G lucose A nalyser 2 (B eckman Instruments, M unich, Germany). Plasma IR -insulin and C-peptide were determined using commercial immunoassay kits. Insulin was measured using an insulin microparticle enzyme immunoassay (MEIA) I M x Insulin, A bbott L aboratories, Wiesbaden, G ermany, which shows a correlation coefficient 0.982 vs R IA 100; Pharmacia, Freiburg, Germany (the assay used in our previous study [15]). Intra-assay coefficients of variation were less than $4.0 \%$. C-peptide was measured using C-peptide antibody-coated microtitre wells (C-peptide M TPL E IA ) from D R G I nstruments $\mathrm{G}$ mbH , (M arburg, G ermany). H uman insulin and $C$-peptide were used as standard.

IR-G L P-1 was determined in ethanol-extracted plasma as previously described [19], using antiserum 89390 (final dilution 1:150 000) and synthetic GLP-1 [7-36 amide] for tracer preparation and as standard. R ecovery of G L P-1 [7-36 amide] standards after alcohol extraction was $75 \pm 8 \%$. The experimental detection limit (2 standard deviations over samples not containing GLP-1 [7-36 amide]) was less than $5 \mathrm{pmol} / \mathrm{l}$. A ntiserum 89390 binds proglucagon-derived peptides containing the amidated carboxy-terminus of G L P-1 [7-36 amide], thereby being relatively specific for G L P-1 [7-36 amide] [20]. Plasma samples with expected high concentrations were diluted 1:10 with assay buffer before analysis.

Pancreatic glucagon was assayed in ethanol-extracted plasma using antibody 4305 [21]. G IP was determined using antiserum $R 65$ and synthetic human G IP for the preparation of standards and ${ }^{125} \mathrm{GIP}$ tracer (purified by HPLC) as described by $K$ rarup et al. [22]. GIP was not measured in the experiments with fasting patients, since G L P-1 [7-36 amide] does not stimulate G IP release in humans $[4,5]$.

Each patient's set of plasma samples was assayed at the same time to avoid errors due to inter-assay variation.

Symptoms. During the experiments, the volunteers were observed and frequently asked about their state of well-being. Their answers were recorded using an open questionnaire.

\section{Statistical analysis}

Subject characteristics are reported as mean $\pm S D$, experimental results are reported as mean \pm SE M. Integration was carried out according to the trapezoidal rule, separately calculating increments over and decrements below mean baseline values. $M$ etabolic clearance rates were calculated as the dose of S. C. G L P-1 [7-36 amide], divided by the integrated incremental response. Significances of differences were tested using repeated measurement analysis of variance (RM-A NOVA; N CSS Version 5.01, K aysville, U tah, U SA ). If a significant interaction of treatment and time was documented $(p<0.05)$, values at single time points were compared by Student's t-test (paired analyses; GLP-1 [7-36 amide] vs placebo). For the analysis of time courses one-way A NOVA was used, followed by t-tests (vs mean basal values), if indicated. For contingency table analysis, a chi square-test was used. A two-sided p-value less than 0.05 was taken to indicate significant differences.

\section{Results}

A II patients were hyperglycaemic at the start of the experiments (mean plasma glucose concentrations over $11 \mathrm{mmol} / \mathrm{l}$; Figs. 1 and 2).

Study A . A single s. C. administration of G L P-1 [7-36 amide] reduced plasma glucose concentrations by approximately $2-3 \mathrm{mmol} / \mathrm{l}$ (Fig. $1 \mathrm{~A}$ ), mainly during the initial $120 \mathrm{~min}$, but the effect was maintained throughout the 240-min period. Insulin (Fig. 1B) and C-peptide (Fig. 1C) were stimulated (peak 30 min after G L P-1 [ 7-36 amide] administration) significantly, 

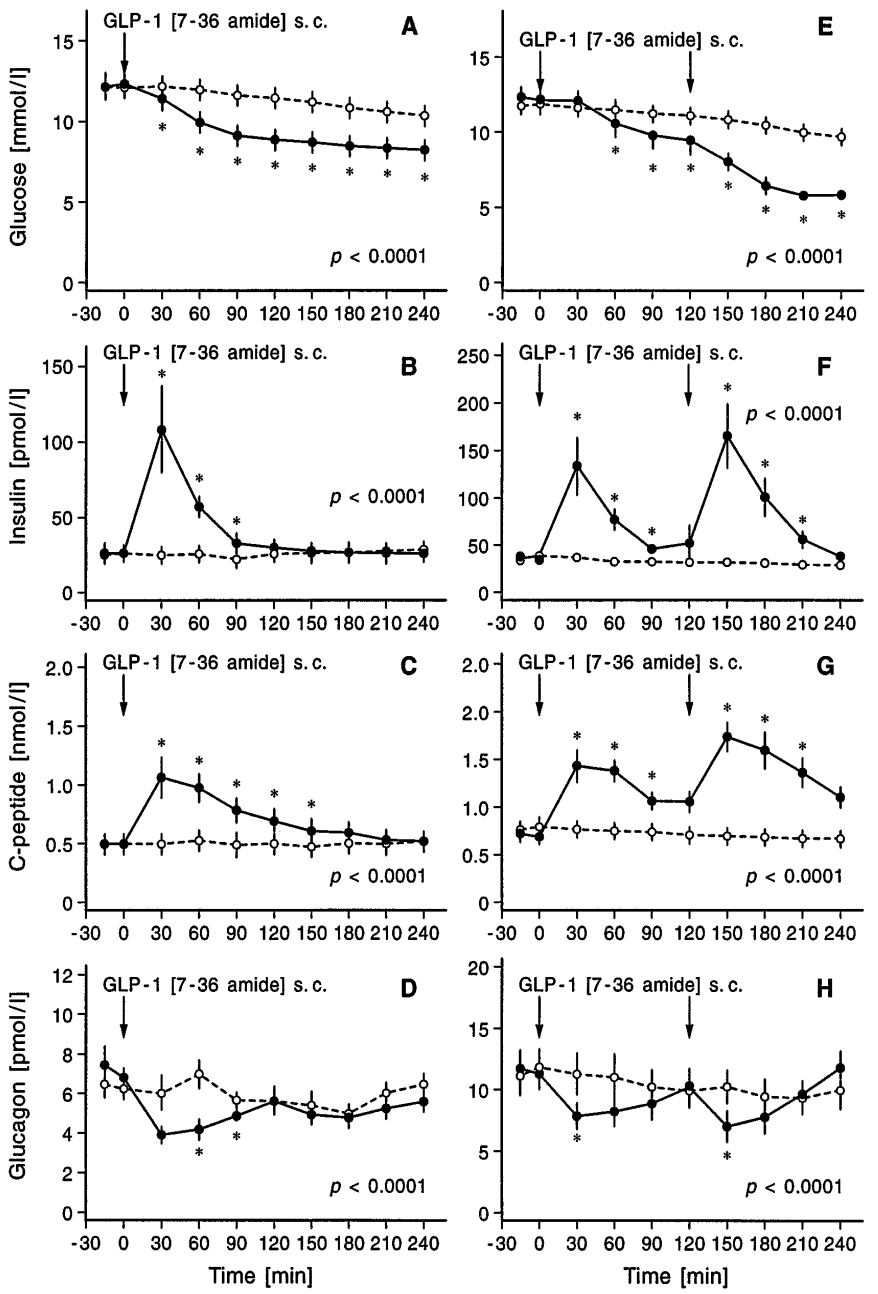

Fig. 1.A - H . E ffects of single (left panels, A-D ) and repeated (right panels, E-H) S.C administrations of GL P-1 [7-36 amide] $(1.5 \mathrm{nmol} / \mathrm{kg}$ body weight) on plasma glucose $(\mathbf{A}, \mathbf{E})$, insulin (B, F) C-peptide $(\mathbf{C}, \mathbf{G})$, and glucagon $(\mathbf{D}, \mathbf{H})$ concentrations in N ID D M patients. A rrows indicate time point of GLP-1 [736 amide] administration. Experiments with GLP-1 [7-36 amide] (•) or placebo (०). P -values indicate significance of interaction of experiment (G L P-1 [7-36 amide] vs placebo) and time. *: D ifferences at specific time points (t-test, $\mathrm{p}<0.05$ )

but transiently, and returned to baseline values after 90-120 (insulin) and 150-180 (C-peptide) min.

G LP-1 [7-36 amide] concentrations reached peak values of around $400-550 \mathrm{pmol} / \mathrm{l} 30-60 \mathrm{~min}$ after S. C. administrations of $1.5 \mathrm{nmol} / \mathrm{kg}$ body weight GLP-1 [7-36 amide] (Fig. 2A) and returned to baseline values within 120-180 min after injection.

G lucagon concentrations were transiently, but significantly ( $p<0.0001)$ suppressed during 90 min after G L P-1 [7-36 amide] administration (Fig. 1D).

Study B. In contrast to the single s. C. administration of G LP-1 [7-36 amide], the repeated administration (two doses administered at 0 and $120 \mathrm{~min}$ ) resulted in a step-wise normalization of fasting glycaemia in NIDDM patients (Fig.1E; $p<0.0001$ vs placebo).
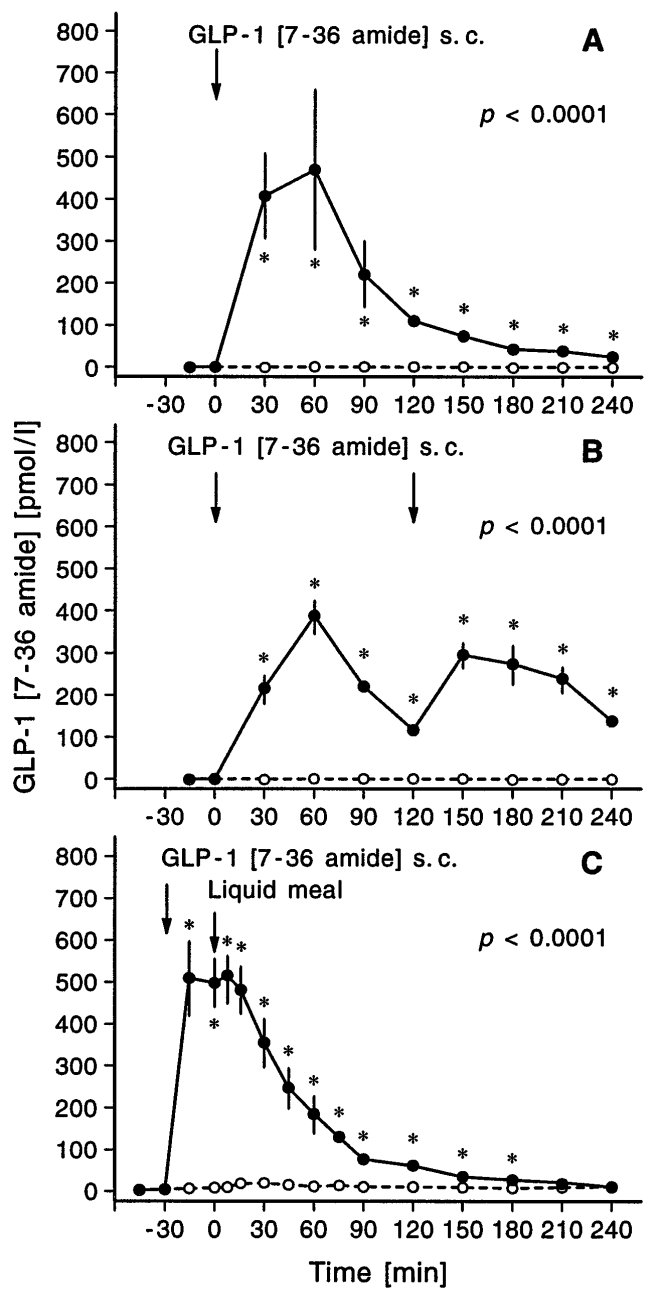

Fig. 2. A - C. E ffects of single (A) and repeated (B) S. C. administrations of G L P-1 [7-36 amide] ( $1.5 \mathrm{nmol} / \mathrm{kg}$ body weight) in the fasting state, and of single (C) S.C. administrations of G L P-1 [7-36 amide] administered before a liquid test meal on plasma GLP-1 [7-36 amide] concentrations in NIDDM patients. A rrows indicate time point of G LP-1 [7-36 amide] administration and of the intragastric installation of the meal. E Xperiments with G L P-1 [7-36 amide] (•) or placebo (o). P-values indicate significance for the interaction of experiment (G L P-1 [7-36 amide] vs placebo) and time. *: Differences at specific time points (t-test, $p<0.05$ )

The plasma glucose reached at the end of the experiment was significantly lower $(5.8 \pm 0.4 \mathrm{mmol} / \mathrm{l})$ than after the single dose $(8.2 \pm 0.7 \mathrm{mmol} / \mathrm{l} ; \mathrm{p}=0.0065$, $\mathrm{t}$ test), while there was no significant difference in the integrated decremental response.

Insulin and C-peptide showed a second increment after the administration of G LP-1 [7-36 amide] at 120 min (Fig. $1 F$ and $G$ ), which made the overall insulin and $C$-peptide responses greater $(p<0.05$ for both) than in the experiment with single doses of GLP-1 [7-36 amide] (Fig. 1B and C). The responses of insulin and $\mathrm{C}$-peptide to the second injection of GLP-1 [7-36 amide] were similar in magnitude to those of the first or single administration (Fig. IF and 

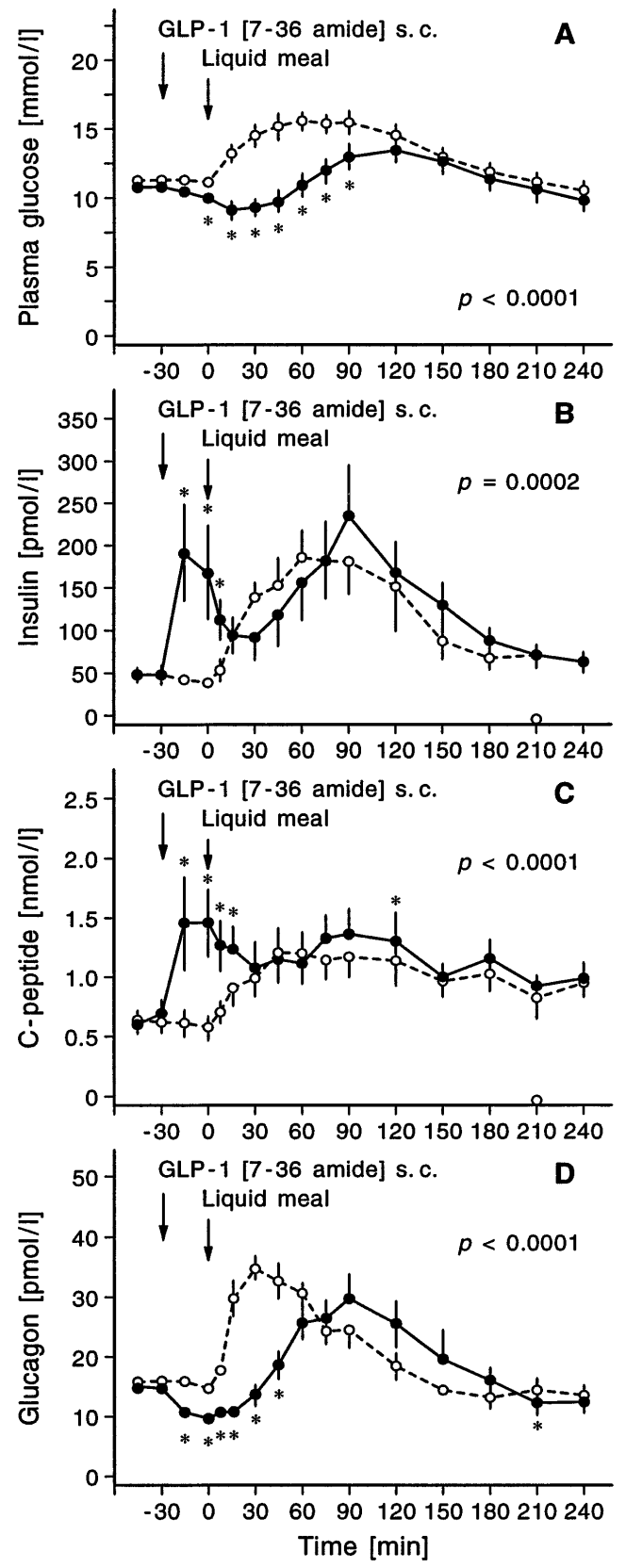

Fig. 3.A-D. Effects of a single S.c. administration of G LP-1 [7-36 amide] (1.5 nmol/kg body weight) on plasma glucose (A), insulin (B), C-peptide (C), and glucagon (D) concentrations in NIDDM patients before and after feeding a liquid test meal. Arrows indicate the time point of GLP-1 [7-36 amide] administration and of the intragastric instillation of the meal. Experiments with G L P-1 [7-36 amide] (•) or placebo (०). $P$-values indicate significance for the interaction of experiment (GLP-1 [7-36 amide] vs placebo) and time. *: Differences at specific time points (t-test, $p<0.05$ )

$G ; p=0.99$ and 0.48 for integrated incremental insulin and C-peptide responses, respectively), although plasma glucose concentrations had al ready been lowered in response to the first injection (Fig. 1E).

G L P-1 [7-36 amide] plasma values showed a second peak of similar magnitude (Fig. 2B), and glucagon

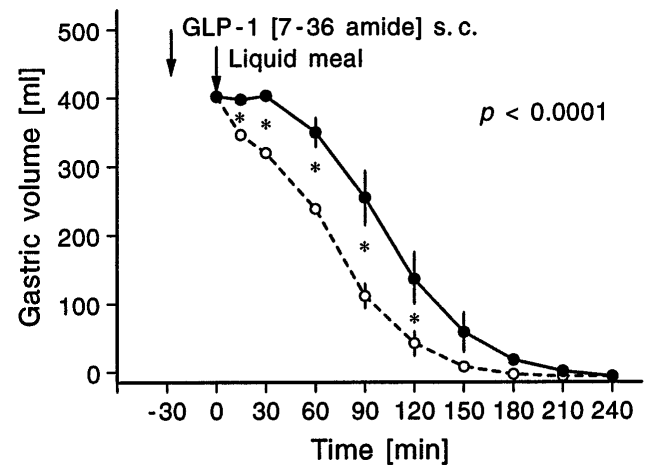

Fig. 4. Effects of single S.c. administrations of GLP-1 [7-36 amide] ( $1.5 \mathrm{nmol} / \mathrm{kg}$ body weight) on gastric emptying rates after the intragastric instillation of a liquid test meal in N ID D M patients. A rrow indicates time point of G L P-1 [7-36 amide] administration. Experiments with G L P-1 [7-36 amide] (•) or placebo (०). P-values indicate the significance for the interaction of experiment (GLP-1 [7-36 amide] vs placebo) and time. *: $D$ ifferences at specific time points (t-test, $p<0.05$ )

concentrations were reduced significantly $(p<0.0001)$ 30 min after each administration ( $\mathrm{Fig}$. $1 \mathrm{H}$ ). The reduction in glucagon was similar after the first and second injection ( $p=0.51)$. However, the overall reduction in glucagon (integrated decremental responses) was not significantly different from experiments with a single dose of G LP-1 [ 7-36 amide].

Study C. I ntragastric instillation of a liquid mixed meal containing $50 \mathrm{~g}$ sucrose, together with the administration of placebo, raised mean plasma glucose concentrations to over $15 \mathrm{mmol} / \mathrm{l}$ (Fig. $3 \mathrm{~A}$ ). H owever, with G L P-1 [7-36 amide] administered S. c. 30 min before the meal, plasma glucose values were lowered rather than elevated during the initial 30-45 min after the meal, with a later rise that was attenuated in comparison with placebo studies (Fig. 3A ). The rise in glycaemia over basal values (integrated incremental responses), however, was only reduced from $529.2 \pm$ $\left.54.3 \mathrm{mmol} \cdot\right|^{-1} \cdot \min$ (placebo) to $318.6 \pm 106.7$ (G L P1 [7-36 amide], which was only of borderline significance $(p=0.051)$. There was a short increment in insulin (Fig. 3B) and C-peptide (Fig. 3C) plasma concentrations during the initial 30 min after GLP-1 [7-36 amide] administration (i.e. before the meal was given), but later insulin and C-peptide curves were similar to those with the placebo. Due to the initial peak in insul in and C-peptide (Fig. 3B and C), the overall integrated incremental insulin ( $21.6 \pm 4.7$ vs $15.9 \pm 3.8$ $\left.\mathrm{nmol} \cdot \mathrm{I}^{-1} \cdot \min , \mathrm{p}=0.0032\right)$ and C-peptide $(139.9 \pm$ 20.6 vs $\left.97.9 \pm 20.1 \mathrm{nmol} \cdot l^{-1} \cdot \min , p=0.0054\right)$ response was greater with S.c G L P-1 [7-36 amide].

The time course of GLP-1 [7-36 amide] plasma concentrations (Fig. 2C) after s.c injection was similar to that described in fasting patients (Fig. $2 \mathrm{~A}$ and $\mathrm{B}$, Table 2). There was a significant increment in G LP-1 [7-36 amide] concentrations after the liquid meal 
Table 2. Integrated incremental responses of GLP-1 [7-36 amide] plasma concentrations after S. C. injection (cf Fig.2) into fasting NIDDM patients and calculated metabolic clearance rates

\begin{tabular}{llll}
\hline Study & $\begin{array}{l}\text { Interval } \\
\text { [min] }\end{array}$ & $\begin{array}{l}\text { Integrated } \\
\text { incremental } \\
\text { GLP-1 } \\
{[7-36 \text { amide] }} \\
{\left[\mathrm{nmol} \cdot \mathrm{I}^{-1} \cdot \mathrm{min}^{-1}\right]}\end{array}$ & $\begin{array}{l}\text { M etabolic } \\
\text { clearance } \\
\text { rate } \\
{\left[\mathrm{ml} \cdot \mathrm{kg}^{-1} \cdot \mathrm{min}^{-1}\right]}\end{array}$ \\
\hline Study A & $0-240$ & $39.5 \pm 11.7$ & $51 \pm 7$ \\
Study B & $0-120$ & $25.6 \pm 2.5$ & $62 \pm 5$ \\
& $120-240^{\mathrm{a}}$ & $25.4 \pm 2.2$ & $62 \pm 5$ \\
Study C & $-30-240$ & $40.9 \pm 5.0$ & $41 \pm 6^{\mathrm{b}}$ \\
A NOVA & & 0.17 & 0.039 \\
(p-value) & & &
\end{tabular}

$D$ ata are mean \pm SE M

a Integration was carried out over true baseline values (measured at -15 and $0 \mathrm{~min}$ ); ${ }^{\mathrm{b}}$ significant difference (Student's ttest; $p<0.05$ ) to both periods of study $B$

with placebo (A NOVA : $p=0.0002$, from basal $7 \pm 1$ to $19 \pm 3 \mathrm{pmol} / \mathrm{l}$ after $30 \mathrm{~min}, p=0.002$ by t-test, also significant vs basal at 45,75 , and $90 \mathrm{~min}$ ).

G lucagon concentrations were elevated by the liquid meal containing amino acids (Fig. 3D) in the placebo study, but with S. C. G LP-1 [7-36 amide] there was a reduction of glucagon values to below fasting values before and shortly after the meal was instilled (Fig. 3D ). L ater, there was a delayed peak of glucagon concentrations (at 90 instead of $30 \mathrm{~min}$ ). The total magnitude of the glucagon response (1347 \pm 163 $\mathrm{pmol} \cdot \mathrm{I}^{-1} \cdot \min$ with G LP-1 [7-36 amide] vs $1428 \pm$ 205 with placebo), however, was not different between GLP-1 [7-36 amide] and placebo administration $(p=0.53)$. Plasma GIP concentrations rose in response to the meal (not shown). G LP-1 [7-36 amide] administration delayed that increment by approximately 45-60 min, also without changing the overall response $\left(3386 \pm 661\right.$ vs $4075 \pm\left. 651 \mathrm{pmol} \cdot\right|^{-1} \cdot \mathrm{min}$, $p=0.19)$.

Subcutaneous G L P-1 [7-36 amide] delayed gastric emptying by $30-45 \mathrm{~min}$, with an initial complete cessation lasting $30 \mathrm{~min}(p<0.0001)$. Thereafter, the time course of gastric emptying was parallel to the placebo studies with the S. c. administration of G LP. 1 [7-36 amide] (Fig. 4). E mptying was near-complete after 150 and $180 \mathrm{~min}$, respectively.

Side effects. In study $A$, one female patient experienced nausea and vertigo $20 \mathrm{~min}$ after the S. c. administration of G L P-1 [7-36 amide]. In study B, nausea and unproductive vomiting occurred with both the first and the second administration of GLP-1 [7-36 amide] in one male patient. B lood pressure and pulse did not change in a clinically relevant fashion during these episodes. In study $\mathrm{C}$, no clinically relevant side-effects were noted; likewise the placebo caused no symptoms.
Pharmacokinetics of G L P-1 [7-36 amide]. Based on integrated incremental GLP-1 [7-36 amide] responses and the dose administered S. c., an apparent metabolic clearance rate of approximately $50 \mathrm{ml}$. $\mathrm{kg}^{-1} \cdot \mathrm{min}^{-1}$ could be calculated (Table 2 ).

\section{Discussion}

The present results show that, with large doses of S.C. G LP-1 [7-36 amide], elevated fasting plasma glucose concentrations in NIDDM patients can be normalized as in previous studies using continuous i.v. administrations of GLP-1 [7-36 amide] or [7-37] [7, 10], provided that plasma G LP-1 [7-36 amide] concentrations are elevated for a prolonged period of time. This was achieved by repeated S. c. injections of G L P-1 [7-36 amide] (Figs. 1 and 2), but it can be extrapolated that similar results can be obtained with continuous S. C. infusions of G LP-1 [7-36 amide] or with a preparation that has retarded absorption kinetics. Such a preparation should elevate plasma G L P-1 [7-36 amide] levels into the effective concentration range $(\sim 100 \mathrm{pmol} / \mathrm{l}$ according to previous studies $[5-7,10,11])$ for a minimum of 3-4 $\mathrm{h}[7,10]$. With such an agent, one could attempt the normalization of fasting glycaemia by an overnight administration. Normal fasting glucose concentrations are an important determinant of overall glycaemic control in NID D M patients $[23,24]$.

It should be considered that not all the G L P-1-like material detected by current radioimmunoassay methods is biologically active G LP-1 [7-36 amide]. $R$ ecent studies have indicated the extent to which G LP-1 [7-36 amide] is subject to proteolytic attack by exopeptidases, giving rise to G LP-1 [9-36 amide], which is totally devoid of biological activity $[25,26]$. This has also been shown during the present experiments (details not shown, see [27]), and is also suggested if one compares the time course of GLP-1 [7-36 amide] concentrations (Fig. 2) as measured by the C-terminal- (amidation-specific) antibody 89390 (see methods) with effects on insulin (Fig. 1B, C, F and $G$ ) and glucagon secretion (Fig. ID and $H$ ). In any case, the duration of elevation of GLP-1 [7-36 amide] above $100 \mathrm{pmol} / \mathrm{l}$ (a concentration that in previous studies led to a constant stimulation of insulin and the suppression of glucagon secretion [7, 10]) was longer than the duration of effects on both insulin and glucagon. This is also evident when interpreting the time course of inhibition of gastric emptying by G L P-1 [7-36 amide]. Such an effect had been noted under the influence of continuous i.v. infusions of GLP-1 [7-36 amide] in normal subjects [28, 29] and in NID D M patients [15, 28]. Furthermore, the inhibition of gastric emptying at plasma levels of 100 $\mathrm{pmol} / \mathrm{l}$ was near-complete for a period of at least 2-4 $\mathrm{h}[15,29]$. In the present experiments (Fig.4), 
gastric emptying was completely stopped for approximately 30 min (i.e. until 60 min after the s. c. administration of G LP-1 [7-36 amide]), but proceeded at a normal rate (as with placebo administration) shortly thereafter, although G L P-1 [7-36 amide] plasma values remained elevated much longer (Fig. 2C). In interpreting the gastric emptying data (Fig.4), the somewhat unphysiological composition of the liquid meal studied should be kept in mind.

In comparison to previous studies using s. C. G L P-1 [7-36 amide] in NIDDM patients, the dose administered was larger in the present examination (approximately fivefold in comparison to G utniak et al. [12]). The effects, as expected, were larger and of longer duration. From the integrated increments in G L P-1 [736 amide] concentrations (Fig. 2) after S. C. administration (Table 2) and the dose administered (1.5 $\mathrm{nmol} / \mathrm{kg}$ ), the apparent metabolic clearance rate (approximately $50 \mathrm{ml} \cdot \mathrm{kg}^{-1} \cdot \mathrm{min}^{-1}$ ) can be calculated, in line with previous results in normal subjects [13]. Since, at plasma concentrations between 100 and 300 $\mathrm{pmol} / \mathrm{l}$, the metabolic clearance rate of G L P-1 [7-36 amide] infused i.v. was approximately $14 \mathrm{ml} \cdot \mathrm{kg}^{-1}$ - $\min ^{-1}[3-5]$, and because there is no reason to believe that the elimination of G L P-1 [7-36 amide] absorbed from S. c. depots should follow different kinetics compared to that of G L P-1 [7-36 amide] administered directly into the bloodstream, the higher metabolic clearance rate after S.c. administration (by approximately 3.5 -fold) probably indicates a reduced bioavailability, which can be estimated to be in the order of $25-30 \%$. The small differences in integrated G L P-1 [7-36 amide] responses between experiments (Table 2) most likely reflect differences in the integration period.

Serious side-effects were not noted; however, nausea and vomiting occurred in 2 of 24 patients studied. In line with our previous study in normal subjects [13], the dose- and concentration range used in the present experiments probably comes close to the maximum to be used in future clinical trials. Hopefully with a slower release of GLP-1 [7-36 amide] from s.c. depots, peak values will be lower and sideeffects should be less likely.

A $s$ in previous studies $[6,12]$, the fall in plasma GLP-1 [7-36 amide] or [7-37] concentrations after administration before a meal resulted in a rebound increment of plasma glucose (Fig. $3 \mathrm{~A}$ ), insulin (Fig. 3B ) and C-peptide (Fig. 3C), when the stomach started to empty again (Fig. 4). Therefore, the reduction in glycaemia was seen only transiently, and the overall effect on the integrated incremental glucose concentrations was of borderline significance only $(p=0.051)$. This may be due to the fact that the $a b$ sorption of meal components is only slightly postponed by the administration of G L P-1 [7-36 amide], as also suggested by the glucagon (Fig.3D) and GIP responses, which remained similar in overall magnitude with the S. c. administration of G LP-1 [736 amide], although their time course was considerably different in comparison to placebo studies (Fig. 3D). If, in fact, glucose concentrations can be normalized in hyperglycaemic NIDDM patients, as has been shown with i. v. G L P-1 [7-36 amide] administrations $[7,10]$, the effects on gastric emptying of G L P-1 [7-36 amide] administered with meals may become the most predominant effect, since the actions on insulin and glucagon secretion are glucose-dependent $[7,10,30]$ and will be of less magnitude at decreasing blood glucose levels. A long this line, the self-limited stimulation of insulin secretion during the i.v. administration of G LP-1 [7-36 amide] [7, 10] probably was, the consequence of the glucose-dependence of this effect. In study $B$, the second injection of G L P-1 [7-36 amide] was still able to stimulate insulin secretion, because normoglycaemia had not been reached with the first dose administered 120 min earlier. A $n$ alternative explanation is that the beta cells had been "primed" by the first injection, which may even potentiate secretory responses to a second stimulation, as has been shown in animal experiments [31].

Based on these considerations, one may speculate that better use can be made of G L P-1 [7-36 amide] in the fasting state than in association with meal ingestion, especially since it has not been completely clarified whether the deceleration of gastric emptying introduced by therapeutic plasma levels of G L P-1 [736 amide] can be considered beneficial [15]. Therefore, one potential therapeutic use of GLP-1 [7-36 amide] could be its overnight administration in order to normalize fasting glycaemia in the morning [23, 24], especially as the normalization of plasma glucose concentrations continued for at least another $4 \mathrm{~h}$ after stopping its administration [10], so that effects lasting longer than the period of administration may be anticipated with such a regimen.

It is of interest to compare the responses to repeated administrations of G L P-1 [7-36 amide], since homologous receptor desensitization has been observed when insulinoma cell lines (carrying G LP-1 receptors) were incubated with large concentrations of G L P-1 [7-37] [32]. Such effects were obvious within 10-40 min. In contrast, in the present experiments, the insulin secretory responses or glucagon suppression were no different when GLP-1 [7-36 amide] was administered a second time within $120 \mathrm{~min}$ (Fig. 1). This was the case although glucose concentrations had already fallen in response to the first G L P-1 [7-36 amide] administration (Fig. 1E ). B ased on the known glucose-dependency of insulinotropic and glucagonostatic actions of G L P-1 [7-36 amide] $[2,7,8,27]$, this reduction in glycaemia alone could have diminished the response to a second administration of GLP-1 [7-36 amide], which was not the case. Therefore, an important short-term tachyphylaxis cannot be deduced from the present study. A long 
this line, GLP-1 [7-36 amide] administered s.c. 3 times daily before meals (dose as in [12]) did not lose its effectiveness over 2 weeks ( $G$ utniak M , E fendic S, personal communication). In diabetic Zucker rats, no loss in effectivity was seen over at least 4 weeks [33]. However, more long-term studies should be performed in humans to clarify this point.

In conclusion, s.c. G LP-1 [7-36 amide] can normalize fasting glycaemia in NIDDM patients, when repeated doses are administered to maintain elevations in G L P-1 [7-36 amide] concentrations over 3$4 \mathrm{~h}$. A retarded-absorption preparation would be preferable for clinical trials. There was no short-term tachyphylaxis of G LP-1 [7-36 amide] effects with repeated dosing. A dministration before meals retarded gastric emptying for 30-60 min, with a delay and only a small overall reduction in glycaemic increments.

A cknowledgements. The excellent technical assistence of M s. S. R ichter, M s. K. H öltner, M s. L. A Ibæk and M r. Th. Gottschling is gratefully acknowledged. This study was supported by the D eutsche Forschungsgemeinschaft, B onn 2 (B ad G odesberg), grant $\mathrm{Na}$ 203/2-2, by the Danish Medical Research Council, and by the N ovo Nordisk Foundation.

\section{References}

1. Ørskov C (1992) Glucagon-like peptide-1, a new hormone of the entero-insular axis. D iabetologia 35: 701-711

2. Creutzfeldt W, Nauck M (1992) Gut hormones and diabetes mellitus. D iabetes M etab R ev 8: 149-177

3. K reymann B, G hatei M A, Williams G, B loom SR (1987) G lucagonlike peptide 1 7-36: a physiological incretin in man. L ancet II:13001304

4. Nauck M, B artels E, Ø rskov C, E bert R, Creutzfeldt W (1993) A dditive insulinotropic effects of exogenous synthetic human gastric inhibitory polypeptide and glucagon-like peptide 1 [7-36 amide] infused at near-physiological insulinotropic hormone and glucose concentrations. J Clin E ndocrinol M etab 76: 912-917

5. N auck M A, H eimesaat M M, Ø rskov C, H olst JJ, E bert R, C reutzfeldt W (1993) Preserved incretin activity of glucagon-like peptide 1 (G L P-1) [7-36 amide] but not of synthetic human gastric inhibitory polypeptide (GIP) in patients with NIDDM . J Clin Invest 91: 301-307

6. Nathan D M, Schreiber E, Fogel H, M ojsov S, H abener J F (1992) Insulinotropic action of glucagon-like peptide-I-(7-37) in diabetic and nondiabetic subjects. D iabetes Care 15: 270-276

7. Nauck M A, K leine N, Ørskov C, H olst J J, Willms B, Creutzfeldt W (1993) N ormalization of fasting hyperglycaemia by exogenous glucagon-like peptide 1 [7-36 amide] in type 2 (non-insulin-dependent) diabetic patients. D iabetologia 36: 741-744

8. Weir G C, M ojsov S, H endrick G K, H abener JF (1989) G lucagonlike peptide I (7-37) actions on endocrine pancreas. Diabetes 38 : 338-342

9. Ørskov C, Wettergren A, Holst JJ (1993) Biological effects and metabolic rates of glucagonlike peptide-17-36amide and glucagonlike peptide -1 7-37 in healthy subjects are indistinguishable. D iabetes 42: 658-661

10. Weber I, B ach-E sser A -K, B ach I et al. (1995) Prolonged normalization of fasting hyperglycaemia by intravenous GLP-1 ([7-36 amide] or [7-37]) in NIDDM patients. Diabetologia 38[Suppl 1]:A 171 (A bstract)

11. G utniak M , Ø rskov C, H olst J J, A hren B , E fendic S (1992) A ntidiabetogenic effect of glucagon-like peptide-1 (7-36)amide in normal subjects and patients with diabetes. N E ngl J Med 326: 1316-1322

12. G utniak M K, Linde B, H olst JJ, E fendic S (1994) Subcutaneous injection of the incretin hormone glucagon-like peptide 1 abolishes postprandial glycaemia in NID D M . D iabetes Care 17: 1039-1044
13. Ritzel R, Ørskov C, H olst JJ, Nauck M A (1995) Pharmacokinetic, insulinotropic, and glucagonostatic properties of GLP-1 [7-36 amide] after subcutaneous injection in healthy volunteers. D ose-response relationships. D iabetologia 38: 720-725

14. N auck M A, Wollschläger $D$, Werner J, H olst JJ, Ø rskov $C$, Creutzfeldt W, Willms B (1995) Effects of subcutaneous glucagon-like peptide 1 (GLP-1 [7-36 amide]) in patients with NIDDM. Diabetologia 38[Suppl 1]:A 39 (A bstract)

15. Willms B, Werner J, H olst J J, Ø rskov C, Creutzfeldt W, N auck M A (1996) G astric emptying, glucose responses and insulin secretion after a liquid test meal: effects of exogenous glucagon-like peptide 1 (GLP-1) [7-36 amide] in type 2 (non-insulin-dependent) diabetic patients. J Clin Endocrinol M etab 81: 327-332

16. Kalorien mundgerecht. 9th edition. U mschau-Verlag, Frankfurt 1993

17. George JD (1968) N ew clinical method for measuring the rate of gastric emptying; the double sampling test meal. G ut 9: 237-242

18. H urwitz A (1981) Measuring gastric volume by dilution. Gut 22 : 85-93

19. Ørskov C, H olst JJ (1987) R adio-immunoassays for glucagon-like peptides 1 and 2 (GLP-1 and G L P-2). Scand J Clin L ab Invest 47: 165-174

20. Ørskov C, R abenhøj L, Wettergren A, Kofod H, Holst JJ (1994) Tissue and plasma concentrations of amidated and glycine-extended glucagon-like peptide 1 in humans. D iabetes 43: 535-539

21. Holst J (1982) Evidence that peak II GLI or enteroglucagon is identical to the $C$-terminal sequence (residues 33-69) of glicentin. Biochem J 207: 381-388

22. K rarup T, M adsbad S, M oody A J, R egeur L, Faber OK, H olst J J, Sestoft L (1983) Diminished gastric inhibitory polypeptide (GIP) response to a meal in newly diagnosed type 1 (insulin dependent) diabetics. J Clin E ndocrinol M etab 56: 1306-1312

23. Holman R R, Turner R C (1977) D iabetes: the quest for basal normoglycaemia. L ancet I:469-474

24. H olman R R, Turner R C (1980) The basal plasma glucose: a simple relevant index of maturity-onset diabetes. Clin Endocrinol 14: 279-286

25. M entlein R, G allwitz B, Schmidt WE (1993) D ipeptidyl-peptidase IV hydrolyses gastric inhibitory polypeptide, glucagon-like peptide-1 (7-36)amide, peptide histidine methionine and is responsible for their degradation in human serum. E ur J B iochem 214: 829-835

26. D eacon CF, J ohnsen A H , H olst JJ (1995) D egradation of glucagonlike peptide- 1 by human plasma in vitro yields an $\mathrm{N}$-terminally truncated peptide that is a major endogenous metabolite in vivo. J Clin Endocrinol M etab 80: 952-957

27. Deacon CF, Nauck M A, Nielsen M, Pridal L, Willms B, Holst JJ (1995) B oth subcutaneously and intravenously administered glucagon-like peptide-1 are rapidly degraded from the amino terminus in type II diabetic patients and in healthy subjects. Diabetes 44 : $1126-1131$

28. Wettergren A, Schjoldager B, M ortensen PE, M yhre J, Christiansen J, Holst JJ (1993) Truncated GLP-1 (proglucagon 87-107amide) inhibits gastric and pancreatic functions in man. $D$ ig $D$ is Sci 38: 665-673

29. Nauck MA, Ettler R, Niedereichholz U, Ørskov C, Holst J], Schmiegel W (1995) Inhibition of gastric emptying by G LP-1 [736 amide] or [7-37]: effects on postprandial glycaemia and insulin secretion. G ut 37[Suppl 2]:A 124 (A bstract)

30. Q ualmann C, N auck M A , H olst J J, Ø rskov C, Creutzfeldt W (1995) Insulinotropic actions of intravenous glucagon-like peptide-1 (G L P-1) [7-36 amide] in the fasting state in healthy subjects. A cta Diabetol 32: 13-16

31. Fehmann HC, G öke R, G öke B, B achle R, Wagner B, A rnold R (1991) Priming effect of glucagon-like peptide-1 (7-36) amide, glucose-dependent insulinotropic polypeptide and cholecystokinin-8 at the isolated perfused rat pancreas. Biochim B iophys A cta 1091: 356-363

32. Fehmann HC, Habener JC (1991) H omologous desensitization of the insulinotropic glucagon-like peptide-I (7-37) receptor on insulinoma (HIT-T 15) cells. E ndocrinology 128: 2880-2888

33. Hargrove D M, Nardone NA, Persson LM, Parker JC, Stevenson RW (1995) G lucose-dependent action of glucagon-like peptide-1 (7-37) in vivo during short- or long-term administration. M etabolism 44: 1231-1237 